
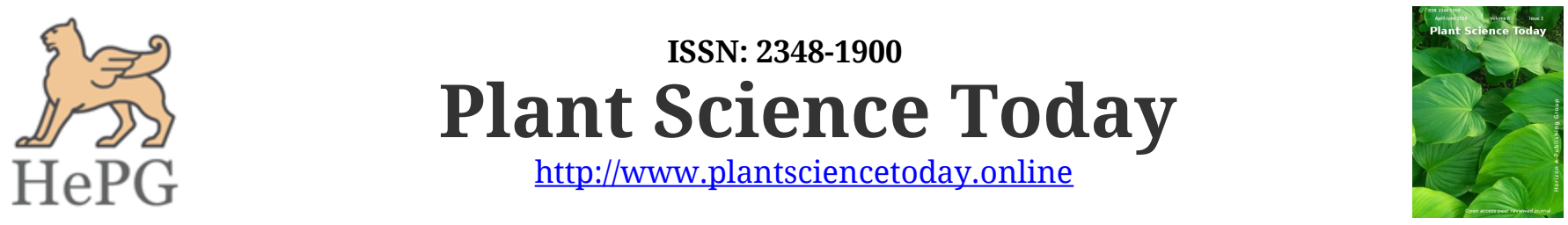

OPEN ACCESS

Research Article

\title{
Formation of medullary phloem in Argyreia nervosa (Burm. f.) Bojer
}

\author{
Kailas K. Kapadane ${ }^{1}$, Ravindra A. Shelke ${ }^{2}$, Amit D. Gondaliya ${ }^{3}$ \& Kishore S. Rajput ${ }^{3 *}$ \\ ${ }^{1}$ Dadasaheb Raval S.V.S. Science College, Dondaicha 455408, Maharashtra, India \\ ${ }^{2}$ Kisan Arts, Commerce and Science College, Parola 425111, Maharashtra, India \\ ${ }^{3}$ Department of Botany, Faculty of Science, The Maharaja Sayajirao University of Baroda, Vadodara 390002, Gujarat, India
}

\section{Article history}

Received: 31 January 2019

Accepted: 27 March 2019

Published: 27 April 2019

\section{Publisher}

Horizon e-Publishing Group

\section{*Correspondence}

Kishore S. Rajput

$\bowtie$ ks.rajput15@yahoo.com

\begin{abstract}
Histologically, family Convolvulaceae is characterised by the presence of successive cambia, medullary (internal/intraxylary) and interxylary phloem in majority of the species, whereas some of the members are devoid of successive cambia and medullary bundles. The present study on Argyreia nervosa (Burm. f.) Bojer showed the presence of medullary bundles while internal phloem was absent during the primary growth. As the secondary growth progressed, successive cambia initiated from the pericyclic parenchyma. Development of medullary bundles began along with the regular protoxylem and protophloem while formation of intraxylary phloem was observed only after the initiation of secondary growth. Medullary/intraxylary sieve elements began to develop from the marginal pith cells. In thick stems, small segments of internal cambium initiated between the protoxylem and internal phloem. This internal cambium was functionally unidirectional and produced internal phloem centripetally. Developmental particulars are described in details along with its significance.
\end{abstract}

Keywords: Argyreia; Convolvulaceae; intraxylary/internal phloem; internal cambium

Citation: Kapadane KK, Shelke RA, Gondaliya AD, Rajput KS. Formation of medullary phloem in Argyreia nervosa (Burm. f.) Bojer. Plant Science Today 2019;6(2):151-159. https://doi.org/10.14719/pst.2019.6.2.498

Copyright: (C) Kapadane et al (2019). This is an open-access article distributed under the terms of the Creative Commons Attribution License, which permits unrestricted use, distribution, and reproduction in any medium, provided the original author and source are credited (https://creativecommons.org/licenses/by/4.0/).

Indexing: Plant Science Today is covered by Scopus, CAS, AGRIS, CABI, Google Scholar, etc. Full list at http://www.plantsciencetoday.online

\section{Introduction}

Climbing habit in the family Convolvulaceae has evolved with various kinds of cambial variants such as successive cambia, internal cambium, successive internal cambia, functionally inverse cambium, interxylary (included phloem), intraxylary (internal) phloem, medullary bundles etc. (1-18). Occurrence of above-mentioned anatomical features are common throughout the family except presence of medullary bundles in the
Convolvulaceae is reported in Argyreia nervosa by Pant and Bhatnagar (10) and in A. nervosa and A. roxburghii by Govil (19).

Medullary bundles are the vascular bundles that are located in the pith region or in the central ground tissue of the plants $(20,21)$. Distribution of medullary bundles in dicots is relatively rare as compared to that of successive cambia and is reported to occur in 49 families (24) and A. nervosa from the Convolvulaceae is one of them. Presence 

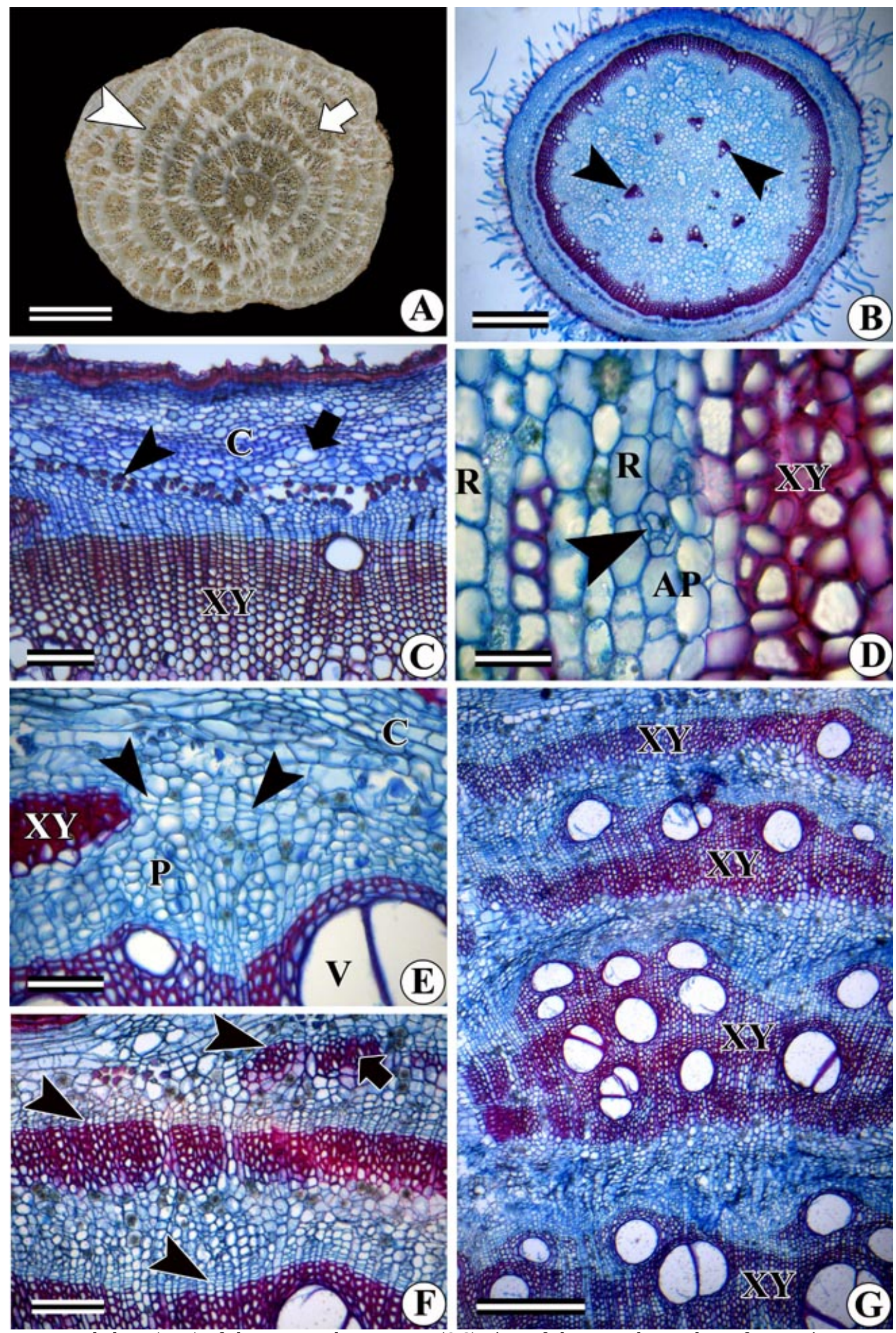

Fig. 1: Macro-morphology (A, B) of the stem and transverse (C-G) view of the secondary xylem of Argyreia nervosa showing structure of secondary xylem and phloem. A: Macro-morphology of fully-grown stem in transverse view showing successive rings of secondary xylem alternating with phloem. Note the fragment ring xylem (arrow) while arrowhead indicates phloem ring. B: Gross structure of young shoot showing its structure with large pith. Note the medullary bundles (arrowheads). C: Young stem (prior to initiation of successive cambium) showing structure and composition. Arrowhead indicates pericyclic fibres while arrow showing laticifer. Abbreviations: $\mathrm{XY}=$ Xylem, $\mathrm{C}=$ Cortex. $\mathrm{D}$ : Transverse section of xylem showing parenchyma island showing interxylary phloem (arrowhead). Abbreviations: $\mathrm{AP}=$ axial parenchyma, $\mathrm{R}=\mathrm{Ray}, \mathrm{XY}=$ xylem. $\mathbf{E}$ : Initiation of successive cambium in young stem. Arrowheads indicates initiating cambium. Abbreviations: $\mathrm{XY}=$ newly formed xylem, $\mathrm{P}=$ phloem formed by vascular cambium, $\mathrm{C}$ = cortex, $\mathrm{V}$ = vessel. $\mathbf{F}$ : Stem portion showing 2-3 active cambia (arrowheads). Arrow showing secondary xylem formed form the newly initiated cambium. G: Successive rings of secondary xylem (XY) formed by the multiple cambia. Scale bar: A $=3$ $\mathrm{mm} ; \mathrm{B}, \mathrm{G}=500 \mu \mathrm{m} ; \mathrm{C}, \mathrm{F}=200 \mu \mathrm{m} ; \mathrm{D}=50 \mu \mathrm{m} ; \mathrm{E}=100 \mu \mathrm{m}$. 
of medullary bundles in $A$. nervosa is reported earlier by Pant and Bhatnagar (10) and Govil $(10,19)$. According to them these bundles may be conjoint, collateral, bicollateral, semi concentric, concentric, amphivasal, amphicrible or obcollateral with well-developed phloem. Medullary bundles undergo secondary thickening due to the cell division activity of the cambium present between the xylem and phloem (10). Similarly, they were explored in detail composition of medullary bundles and their types in $A$. nervosa. However, presence of secondary growth in these bundles is not documented earlier. Similarly, number of medullary bundles may vary from species to species and age of the of the same species.

Stem anatomy of the $A$. nervosa is thoroughly investigated and reported presence of medullary bundles, development of successive cambia and unique morphology of the sieve elements in normal and variant phloem (10). In their study, stem anatomy, development of successive cambia and medullary bundles have been described in detail. However, no much attention is paid to study the development of medullary/intraxylary phloem. Therefore, present investigation is aimed to illusedate the structural details and development of intraxylary phloem in Argyreia nervosa (Burm. f.) Bojer.

The gross anatomy of the stem and development of successive cambia is described in brief while development of intraxylary phloem is studied in detail. Additionally, we also report development of internal cambium and secondary growth in the medullary bundles.

\section{Materials and Methods}

Samples from the main stems and young branches starting from apical tip up to top 25 internodes were collected from Argyreia nervosa (Burm. f.) Bojer (Convolvulaceae) growing naturally in Girnar Taleti and in the arboretum of the M. S. University of Baroda, Vadodara. Samples were also collected from the main stems up to maximum thickness available. The maximum thickness available in our study was $125 \mathrm{~mm}$. Five individuals each were cut from both the localities at various heights from the ground level up to the apical tip and fixed immediately in FormaldehydeAcetic acid-ethyl Alcohol (10:5:85 v/v) (22). Subsequently, after arriving to the laboratory, samples were kept in vacuum for removal of air bubbles and better preservation of the samples. After $24 \mathrm{hrs}$ of fixation, these samples were transferred to $70 \%$ alcohol for further processing and storage.

For microscopic study, thick stem samples were sectioned directly with the help of Leica SM2010R) sliding microtome. Young stems and apical shoots were trimmed into suitable size (2-3 $\mathrm{mm}$ ) pieces and dehydrated through Tertiary Butyl Alcohol (TBA) and impregnated with paraffin wax and processed through routine method (22). Paraffin blocks were sectioned with the help of rotary microtome (Leica RM 2035). Sections of 15$20 \mu \mathrm{m}$ thick were cut in transverse, radial and tangential longitudinal plains and stained with Safranin-Astra blue combination (23). Slides were mounted in Dibutyl Phthalate Xylene (DPX) after dehydrating through ethanol-xylene series. Important results were observed using Leica DME 2000 trinocular microscope and microphotographs were obtained using digital camera (Leica DFC 295) fitted on it.

\section{Results}

Stem anatomy: Thick stems of fully grown Argyreia nervosa were composed of several successive rings of secondary xylem alternating with phloem (Fig. 1A). The young stems were composed of barrel shaped single layered epidermis with several hairs projecting out from them (Fig. 1B). The cortex lies beneath the epidermis and consisted thin-walled oval to polygonal parenchyma cells (Fig. 1C). Several laticifers were embedded randomly within the cortex (Fig. 1C). Large sized cortical parenchyma showed accumulation of druses. Cortex was separated by a distinct layer of pericyclic fibre (Fig. 1C). Pith was composed of thin walled parenchymatous cells with irregularly distributed laticifers and 6-8 medullary bundles (Fig. 1B). With the increase in age, several conjoint collateral vascular bundles interconnect to form continuous ring of vascular cambium. The vascular cambium was functionally bidirectional and produced secondary xylem centripetally and secondary phloem centrifugally. The xylem was diffuse porous with indistinct growth rings and composed of vessels (both wide and fibriform), tracheids, fibres, axial and ray parenchyma cells. Patches of thin walled axial parenchyma were randomly distributed within the secondary xylem. In adult plants, these parenchyma cells underwent dedifferentiation and formed interxylary phloem (Fig. 1D). After a short period of activity, vascular cambium ceased to divide and a new ring of vascular cambium initiated from the pericyclic derivatives (Fig. 1E). In thick stems 2-3 successive cambia were found active within the same stem (Fig. 1F). Subsequent increase in stem thickness was achieved by forming successive cambia in the similar fashion as described above (Fig. 1E, G).

Structure of pith in fully grown stems: Pith of the fully-grown thick stems consisted quantifiable amount of intraxylary phloem, internal cambium, several medullary bundles and laticifers were intermixed in the ground mass of pith cells (Fig. 2A, B). Young stems possessed only 6-8 medullary bundles (Fig. 1B) but as the secondary growth progressed, their number increased up to 64 (Fig. 

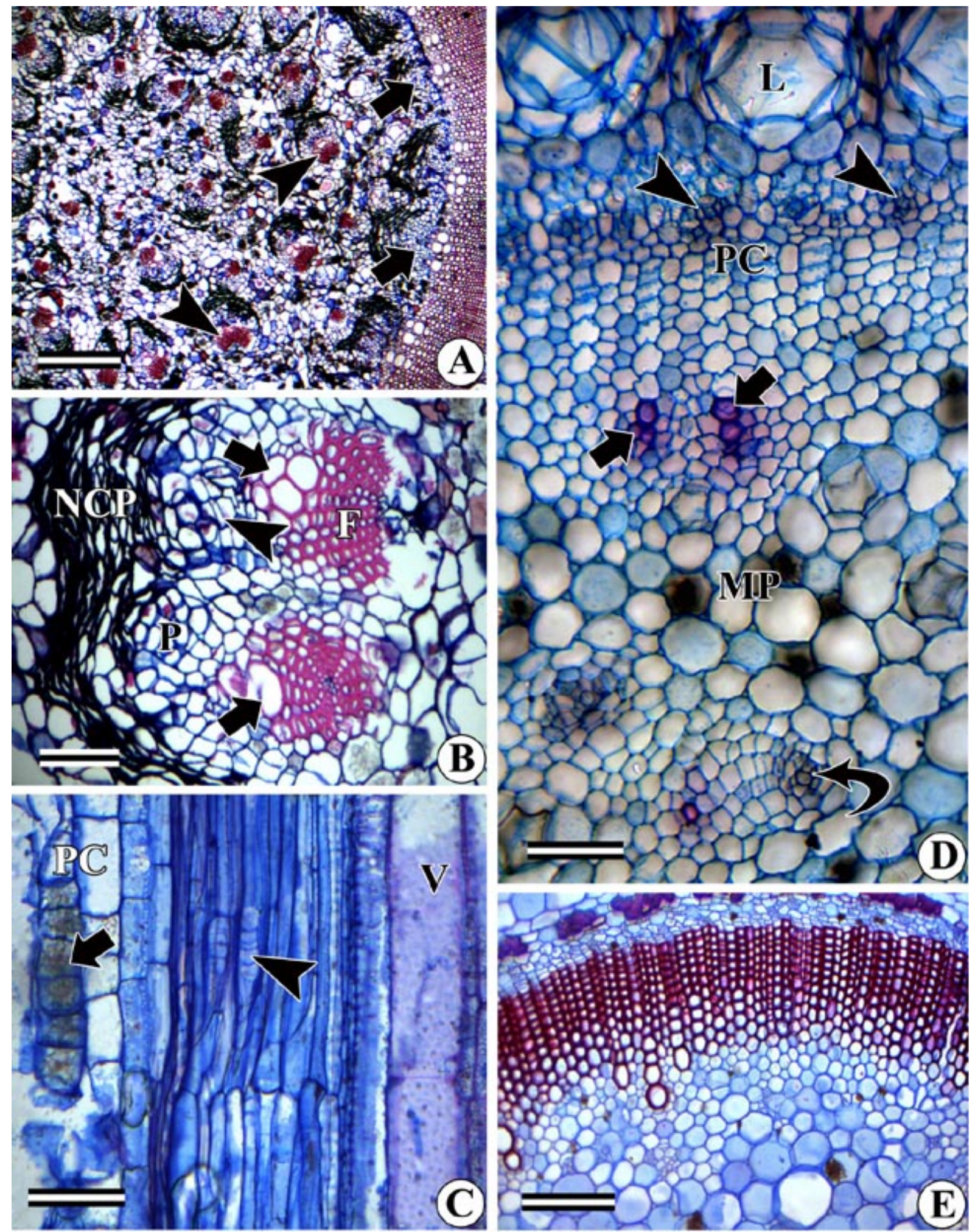

Fig. 2: Transverse (A, B, D, E) and radial longitudinal view (C) of Argyreia nervosa stem. A: Fully grown stem showing several medullary bundles in the pith (arrowheads). Arrow indicates internal phloem. B: Medullary bundle in the thick stem showing composition of the xylem. Arrows indicates vessel elements while arrowheads show cambium. Abbreviations: $\mathrm{P}=\mathrm{Phloem}$, NCP = Nonconducting phloem, $\mathrm{F}$ = fibres. C: Compound-scalariform sieve plates of the sieve elements of the medullary bundles (arrowhead). Arrow indicates druses in the pith cells. Abbreviations: $\mathrm{PC}=$ Pith cells, $\mathrm{V}=$ vessel element of medullary bundle. D: Young shoot showing differentiating protophloem (arrowhead), protoxylem (arrow) and medullary bundles (curved arrow). Note the marginal pith cells (MP) between protoxylem and medullary bundles. Abbreviations: $\mathrm{L}=$ laticifer, $\mathrm{PC}=$ Procambium. E: Young stem showing absence of intraxylary phloem on the pith margin. Scale bar: $A=500 \mu \mathrm{m} ; \mathrm{B}, \mathrm{C}=100 \mu \mathrm{m} ; \mathrm{D}=50 \mu \mathrm{m} ; \mathrm{E}=200 \mu \mathrm{m}$.

2A). They were mostly composed of fibres in young stems but with the increase in the age of plants, cambial action takes place and form 2-3 vessel elements (Fig. 2B). Though, the cambium was diffuse, in each medullary bundle considerable amount of secondary phloem was observed in all the medullary bundles (Fig. 2B). Accumulation of non-conducting and obliterated phloem with functional sieve elements are also evidence of cambial activity in them and they undergo secondary growth (Fig. 2B). Obliteration of sieve elements resulted due to addition of new sieve that 


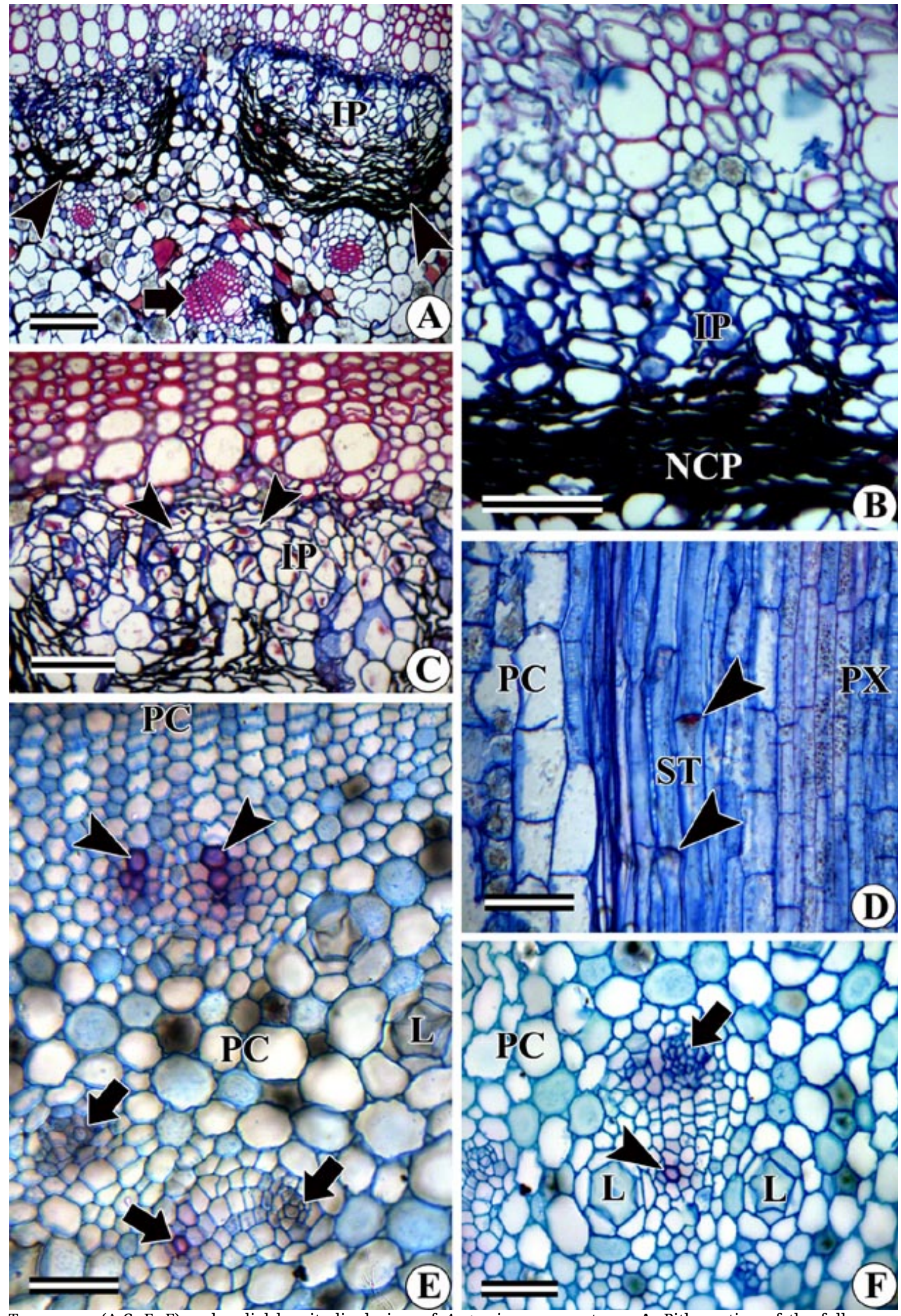

Fig. 3: Transverse (A-C, E, F) and radial longitudinal view of Argyreia nervosa stem. A: Pith portion of the fully-grown plant showing intraxylary phloem (IP). Note the non-conducting intraxylary phloem (arrowheads). Arrow showing medullary bundle. B: Enlarged view showing intraxylary phloem (IP) and non-conducting and crushed phloem (NCP). C: A thick stem showing intraxylary phloem (IP) and diffuse internal cambium (arrowheads). D: Enlarged view of the pith margin showing internal (intraxylary) phloem. Note the transversely arranged simple sieve plate (arrowheads). Abbreviations: PC $=$ pith cells, PX $=$ parenchyma cells of protoxylem, ST = sieve tube elements. E: Part of the pith showing differentiating protoxylem (arrowheads) from the regular cambium while arrow indicates differentiating medullary bundles (arrows showing xylem and phloem). Note the pith cells (PC) that separate product of procambium and medullary bundle. Abbreviations: $\mathrm{L}=$ laticifers, $\mathrm{PC}=$ pith cells. $\mathbf{F}$ : Enlarged view of differentiating medullary bundle in young stem showing differentiating xylem (arrowhead) and phloem (arrow). Abbreviations: $\mathrm{L}=$ laticifers, $\mathrm{PC}=$ pith cells. Scale bar: $\mathrm{A}, \mathrm{B}=200 \mu \mathrm{m} ; \mathrm{C}, \mathrm{D}=100 \mu \mathrm{m} ; \mathrm{E}, \mathrm{F}=50 \mu \mathrm{m}$. 
elements that wield a pressure on the earlier formed phloem elements (Fig. 2B). These bundles do not have specific orientation and they may be radially, tangentially or diagonally oriented in the pith (Fig. 2A). Sieve elements of these bundles were characterised by the presence of obliquely oriented compound-scalariform sieve plates while horizontally arranged simple sieve plate were observed occasionally (Fig. 2C).

Beside medullary bundles, delayed development of intraxylary phloem was also observed at the pith margin (Fig. 2D). In relatively young stems, intraxylary phloem was found absent at the pith margin (Fig. 2E) while in thick stems inner margin of the protoxylem showed presence of intraxylary phloem (Fig. 3A). It was composed of sieve elements, companion cells and axial parenchyma (Fig. 3B, C). In thick stem, a diffuse (weak) internal cambium develops between the intraxylary phloem and protoxylem elements (Fig. 3C). This cambium was functionally unidirectional and gave rise to only phloem elements while differentiation of xylem was not observed as reported in several other members of this family. In contrast to regular (external) and phloem of medullary bundles, sieve elements of the intraxylary phloem possessed horizontally arranged simple sieve plates on their terminal ends (Fig. 3D). As the time passes, additional sieve elements were added from the marginal pith cells while earlier formed sieve elements get pushed towards the centre resulted in obliteration (Fig. 3A, B).

Development of medullary bundles and intraxylary phloem: Development of medullary bundles precedes that of intraxylary phloem and initiates more or less simultaneous with the protoxylem (Fig. 3E, F). During the development of these bundles, differentiation of only sieve elements initiates as strands of phloem that were distributed randomly within the ground mass of pith cells (Fig. 3F). Subsequently, differentiation of xylem derivatives took place on its either side (Fig. 3F). Orientation of these bundles was not specific and they may be radially, tangentially or diagonally oriented (Fig. 2A). As the time passes, additional xylem derivatives were added in these bundles, which consequently resulted into medullary bundles that may be bicollateral, semi concentric, concentric, amphivasal, amphicrible or obcollateral in nature. The sieve elements formed in the beginning of their development and in the fully developed bundles showed drastic variations in their diameter (Fig. 3A-C) and in the length of the sieve tube elements. In the young stems they were 18-23 $(20 \pm 1.228) \mu \mathrm{m}$ in diameter and 139$197(170 \pm 3.193) \mu \mathrm{m}$ length while in fully grown stems they measured 27-42 $(35 \pm 0.541) \mu \mathrm{m}$ in diameter and 379-564 (468 \pm 3.235$) \mu \mathrm{m}$ in length.

Development of intraxylary phloem was observed only after the initiation of secondary growth and development of secondary xylem (Fig.
$4 \mathrm{~A}-\mathrm{C})$. As the secondary growth progressed, pith cells 3-4 cells inside in the radial direction of the protoxylem underwent differentiation into intraxylary sieve elements (Fig. 4D, E). However, in 2 samples that were collected from Girnar Hills showed simultaneous development of intraxylary protophloem and external protophloem (Fig. 4F). Similar to the phloem of medullary bundles, intraxylary sieve elements formed in the beginning possessed relatively narrow diameter than the sieve elements formed in the thick stems (Figs. 3D, 4F). Similar to the medullary bundles, earlier formed sieve elements of the intraxylary phloem became non-conducting and underwent obliteration and accumulated centripetally as a mass of crushed sieve elements (Fig. 3A, B). Intraxylary phloem was composed of sieve elements, companion cells and axial parenchyma cells while no ray cells were observed as reported in other members of the Convolvulaceae.

\section{Discussion}

Stem anatomy of the family Convolvulaceae is unique and shows various types of variant growth patterns such as development of successive cambia, interxylary phloem, intraxylary phloem, internal cambium, successive internal cambia or presence of medullary bundles $(2,3,7,10-12,16-18)$. Though, these features are common in most of the species of the family, formation of successive cambia lack in members viz., Convolvulus, Cressa and Wilsonia. On the other hand, occurrence of intraxylary/medullary/internal phloem is constant feature in all the members of the family studied so far (1-18). In the present study, Argyreia nervosa (Burm. f.) Bojer (Convolvulaceae) showed formation of successive cambia, development of medullary bundles and intraxylary phloem $(10,19)$.

In thick stems, development of interxylary phloem was observed from the parenchyma islands that are formed in the beginning of the secondary growth. Similar kind of interxylary phloem development from the thin walled parenchyma cells of the secondary xylem in the family Convolvulaceae have been reported previously (11-13,24-26). Unlike other members of the family, included or interxylary phloem is formed as isolated strands of 1-2 sieve elements and that could be the reason that Pant and Bhatnagar (10) failed to detect the same in their study. In the genus Ipomoea (another member of the family Convolvulaceae), interxylary phloem initiates by dedifferentiation of axial parenchyma, which leads to the formation of interxylary phloem islands $(13,15)$ that were composed of group sieve elements (11-13). Various functions have been ascribed to the occurrence of interxylary phloem (26) and we believe that it plays as important role as an alternative path way for the translocation of photosynthates. Though, there are other alternate ways to achieve this function (26). 

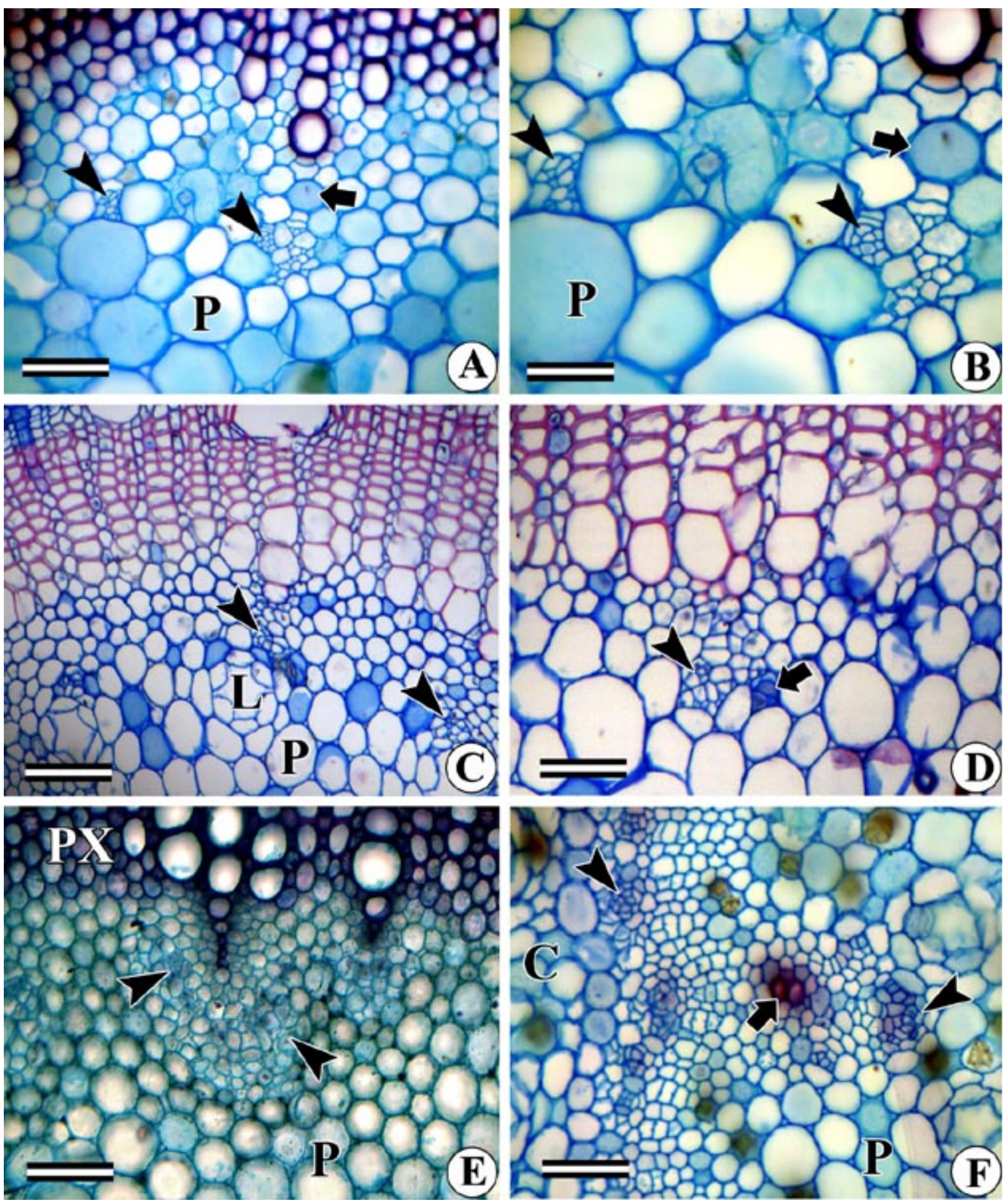

Fig. 4: Transverse view of young stems of Argyreia nervosa. A: Absence of intraxylary phloem at the pith margin. Arrowheads indicate differentiating medullary bundles. Note that pith cells that separate protoxylem and phloem medullary bundle. Abbreviation: P = pith cell. B: Enlarged view of figure 4A showing absence of intraxylary phloem. Note that pith cells that separate protoxylem and phloem of medullary bundle (arrowhead). Abbreviation: $\mathrm{P}=$ pith parenchyma. Abbreviation: $\mathrm{P}=$ pith cell. C: Initiation of intraxylary phloem development (arrowheads). Note amount of secondary xylem formed by the vascular cambium. Abbreviations: $\mathrm{L}=$ laticifers, $\mathrm{P}=$ pith cells. D: Enlarged view of pith portion showing differentiating intraxylary phloem. Arrow shows well developed sieve element. E: Relatively thick stem showing quantitative amount intraxylary phloem formed at the pith margin (arrowheads). Abbreviations: PC = pith cells, PX = protoxylem. F: Simultaneous differentiation of regular (left arrowhead) and intraxylary (right arrow) phloem. Arrow indicates protoxylem. Note the absence of pith cells between protoxylem and intraxylary phloem. Abbreviations: $\mathrm{C}=$ cortex, $\mathrm{P}=$ pith cells. Scale bar: $\mathrm{A}, \mathrm{C}, \mathrm{E}=100 \mu \mathrm{m} ; \mathrm{B}, \mathrm{D}, \mathrm{F}=50 \mu \mathrm{m}$.

Development of successive cambia from the parenchymatous cells located inside the pericycle become meristematic and give rise to first ring of successive cambium. Our observations on initiation of successive cambia and types of medullary bundles are in agreement with the previous reports on Argyreia nervosa (10). However, in the present study, development of intraxylary phloem differs from the previous report (10). According to them, procambial cells give rise to intraxylary phloem in patches and residual meristem forms outer and inner cambia. This interpretation indicates that $A$. nervosa shows bicollateral nature of the vascular bundles. As shown in figures 2D, E and 4A-D, none of the stem section showed bicollateral nature of vascular 
bundle, rather the phloem patches observed in the pith region that are situated deep inside the pith and separated from the protoxylem by conspicuous and morphologically different (pith) cells. Authors also believe that the regular vascular bundles of $A$. nervosa are not bicollateral and internal phloem develops from the pith cells. Herail (27) elucidated that bicollateral bundles exist only in Cucurbitaceae whereas in other families internal phloem originates from the pith cells. Similar opinion is given by Lamounette (28), Lee (29) and Heyward (6) believed that, it initiated independently from the parenchyma cells which are adjacent to the procambial cells.

As shown in figures $2 \mathrm{E}$ and $4 \mathrm{~A}, \mathrm{~B}$, internal phloem is absent on the inner margin of the protoxylem till the development of complete ring of vascular cambium and showed considerable delay in its development. Development of intraxylary phloem has been reported from the procambial cells by Pant and Bhatnagar (10, p 60, L: 7-11). However, our observations on the development internal phloem differ from those of Pant and Bhatnagar (10). However, present study demonstrates that its development takes place only after the initiation of secondary growth. Therefore, internal phloem development in $A$. nervosa is not procambial in origin and it develops independently from the pith cells. This statement may also be supported with figure $4 \mathrm{~A}$ and $\mathrm{B}$ that shows periphery of pith (i.e. adjacent to protoxylem derivatives) is free from the medullary phloem. Delayed development of internal phloem from the pith cells is also reported in Convolvulaceae (Cressa cretica) (14) and in Bignoniaceae (Campsis radicans) (30). As shown in figure $4 \mathrm{~F}$, some of the samples also showed development of internal phloem more or less simultaneously with the regular external phloem and lack of pith cells (that are morphologically different) on the adaxial side of the protoxylem derivatives.

Formation of intraxylary phloem is universal in Convolvulaceae and in most of the members, internal cambium initiates at the pith margin i.e. centrifugally to the intraxylary phloem $(8,11-13,17,18,25,26,31)$. In the present study, also observed periclinal divisions at the marginal pith cells between protoxylem and intraxylary phloem and results into a weak cambium (i.e. 2-3 meristematic cells in radial file). The internal cambium may be functionally unidirectional (producing only phloem) or bidirectional i.e. produce xylem centripetally and phloem centrifugally $(12,13,18,31)$. Handa (32) reported a unique case of unidirectional cambium in Hoya carnosa and Marsdenia tomentosa (s.f. 8). According to Handa (32), in both the species differentiation of xylem and phloem takes place in the same directions i.e. internal cambium first produce intraxylary phloem followed by secondary xylem derivatives. Similar observations have also been reported by Rajput and Gondaliya (31) in Ipomoea turbinata. However, in the present study, even in $125 \mathrm{~mm}$ thick stems no xylem differentiation was observed from the internal cambium. These sieve elements are characterised by the presence of horizontally arranged simple sieve plates while regular (external) phloem showed compound scalariform showing both advanced and primitive features (10).

\section{Conclusion}

Stem diameter in Argyreia nervosa increases by forming successive cambia. Interxylary phloem differentiates in the earlier formed parenchyma islands while intraxylary phloem differentiates from the marginal pith cells and not from the procambial cells/derivatives. Internal cambium is unidirectional in nature add further intraxylary phloem. Development of medullary bundles initiates more or less simultaneous to procambium and their number increases with the increase in age of the plants.

\section{Acknowledgements}

Authors are thankful to University Grants Commission and Department of Science and Technology, Government of India for financial support under UGC-DRS and DST-FIST programme respectively.

\section{Competing interests}

The authors declared that they have no competing interest.

\section{Authors' contributions}

KKK and RAS collected the specimens from the field and wrote the initial draft of the manuscript, ADG prepared the slides, micro-photographed and analysed the data, KSR supervised the project and finalized the MS.

\section{References}

1. Vesque J. Mémoire sur l'anatomie comparé de l' écorce. Ann des Sci Nat, Bot. VI. 1875;2:82-198.

2. De Barry A. Comparative anatomy of the vegetative organs of the Phanerogams and ferns. (Transl. Bower F. O. and Scott D. H.), Oxford. P 1884.

3. Scott DH, Brebner G. On internal phloem in the root and stem of dicotyledons. Ann Bot. 1891;5:259-300. https://doi.org/10.1093/oxfordjournals.aob.a090640

4. Schenck H. Beiträgezur biologie und Anatomie der Lianen. II. Schimpers Botanischen Mittheilungen Tropischen 1893;5:1-271.

5. Artschwager E. On the anatomy of the sweet potato root, with notes on internal break down. J Agri Res. $1924 ; 14: 221-252$. 
6. Heyward HE. The seedling anatomy of Ipomoea batatas. Bot Gaz. 1932;93:400-420. https://doi.org/10.1086/334271

7. Metcalfe CR, Chalk L. Anatomy of the dicotyledons. Oxford, Clarendon Press. P 1950.

8. Fukuda Y. Anatomical study of the internal phloem in the stems of dicotyledons, with special reference to its histogenesis. J Fac Sci, Univ Tokyo III 1967;9: 313-375.

9. Mennega AMW. The wood structure of Dicranostyles (Convolvulaceae). Acta Bot Neerl. 1969;18:173-179. https://doi.org/10.1111/j.1438-8677.1969.tb00582.x

10. Pant DD, Bhatnagar S. Morphological studies in Argyreia Lour. (Convolvulaceae). Bot J Linn Soc. 1975;70:45-69. $\quad$ https://doi.org/10.1111/j.10958339.1975.tb00678.x

11. Lowell C, Lucansky TW. Vegetative anatomy and morphology of Ipomoea hederifolia (Convolvulaceae). Bull Torrey Bot Club 1986;113:382-397. https://doi.org/ $\underline{10.2307 / 2996431}$

12. Carlquist S, Hanson MA. Wood and stem anatomy of Convolvulaceae: a survey. Aliso 1991;13:51-94. https:// doi.org/10.5642/aliso.19911301.03

13. Rajput KS, Rao KS, Patil VS. Wood Anatomy and the development of interxylary phloem of Ipomoea hederifolia Linn. (Convolvulaceae). J Plant Growth Regul. 2013;32:654-662. https://doi.org/10.1007/s00344$\underline{013-9334-8}$

14. Rajput KS, Patil VS, Rao KS. Stem anatomy of the dwarf subshrub Cressa cretica L. (Convolvulaceae). Flora 2014a;209:408-413. https://doi.org/10.1016/j.flora.2014.06.006

15. Rajput KS, Patil VS, Rao KS. Multiple cambia and secondary xylem of Ipomoea pes-caprae (L.) R. Br. (Convolvulaceae). Acta Bot Gallica 2014b;161(1):13-19. https://doi.org/10.1080/12538078.2013.847020

16. Rajput KS, Lekhak MM, Kapadane KK, Yadav SR. Formation of trilobbed stem and successive cambia in the stems of Argyreia hookeri C. B. Clarke (Convolvulaceae). Flora 2017;233:140-149. https://doi.org/10.1016/j.flora.2017.06.005

17. Terrazas $\mathrm{T}$, Aguilar-Rodríguez $\mathrm{S}$, Ojanguren $\mathrm{CT}$. Development of successive cambia, cambial activity, and their relationship to physiological traits in Ipomoea arborescens (Convolvulaceae) seedlings. Amer J Bot. 2011;98:765-774. https://doi.org/10.3732/ajb.1000182

18. Lekhak MM, Gondaliya AD, Yadav SR, Rajput KS. The stem anatomy at various developmental stages of secondary growth in Turbina corymbosa (L.) Raf. (Convolvulaceae). Plant Ecol and Evol. 2018;51(2):219230. https://doi.org/10.5091/plecevo.2018.1389
19. Govil CM. Developmental studies in Argyreia nervosa Boj., In: Puri V. (Eds). Symposium on the biology of land plants. Meerut University, Meerut (India). 1972.

20. Cutler DF, Botha CEJ, Stevenson DW. Plant anatomy: an applied approach. Blackwell Publishing Ltd., Malden, USA. 2007;P 1-302.

21. Beck CB. An introduction to plant structure and development ( nd $^{\text {Ed }}$ ). Cambridge University Press, Cambridge, New York 2010;P 1-441. https://doi.org/10.1017/CBO9780511844683

22. Johansen DA. Plant Microtechnique. McGraw Hill, New York. 1940.

23. Srebotnik E, Messener K. A simple method that uses differential staining and light microscopy to assess the selectivity of wood delignification by white rot fungi. Appl Environ \& Microbiol. 1994;60:1383-1386

24. Metcalfe CR, Chalk L. Anatomy of dicotyledons. II. Clarendon Press, Oxford. 1983.

25. McDonald JA. Evolutionary implications of typical and anomalous secondary growth in arborescent Ipomoea (Convolvulaceae). Bull Torrey Bot. Club 1992;119:262267. https://doi.org/10.2307/2996757

26. Carlquist S. Interxylary phloem: diversity and functions. Brittonia 2013;65(4): 477-495. https://doi.org/10.1007/s12228-012-9298-1

27. Herail J. Recherches sur l'anatomie comparée de la tige des dicotylédones. Ann des Sci Nat Botanique1885;2:203-214.

28. Lamounette B. Recherches a l'etude du liber des angiospermes. Ann des Sci Nat Botanique (ser 7) 1889;10:193-324.

29. Lee E. Observations on the seedling anatomy of certain sympetalae. I. Tubiflorae. Ann Bot. 1912;26: 727-746. https://doi.org/10.1093/oxfordjournals.aob.a089412

30. Rajput KS, Gondaliya AD, Lekhak MM, Yadav SR. Structure and ontogeny of intraxylary secondary xylem and phloem development by the internal vascular cambium in Campsis radicans (L.) Seem (Bignoniaceae). J Plant Growth Regul 2018;37:755-767. https://doi.org/10.1007/s00344-017-9771-X

31. Rajput KS, Gondaliya AD. Internal cambium and intraxylary phloem development in Ipomoea turbinata Lag. (Convolvulaceae). Flora 2017;226:47-54. https://doi.org/10.1016/j.flora.2016.11.002

32. Handa T. Anatomical observations on the internal cambium of the stem in Marsdenia tomentosa Morr. et Dence. Jap J Bot. 1937;8: 59-64. 